\title{
Emergy based sustainability evaluation of spent lead acid batteries recycling
}

\author{
Jianping Yu ${ }^{\text {a,c }}$, Jintang Yang ${ }^{a, *}$, Zhigang Jiang b,* , Hua Zhang ${ }^{b}$, Yan Wang ${ }^{d}$ \\ ${ }^{a}$ Key Laboratory of Metallurgical Equipment and Control Technology, Wuhan University of Science \\ and Technology, Wuhan, China; \\ ${ }^{b}$ Hubei Key Laboratory of Mechanical Transmission and Manufacturing Engineering, Wuhan \\ University of Science and Technology, Wuhan, China; \\ ${ }^{c}$ Electronic Information Engineering School of Jingchu University of Technology, Jingmen, China; \\ ${ }^{d}$ Department of Computing, Engineering and Mathematics, University of Brighton, Brighton BN2 \\ 4GJ, United Kingdom.
}

Corresponding authors: Jintang Yang, yangjintang@wust.edu.cn; Zhigang Jiang, jiangzhigang@wust.edu.cn

\begin{abstract}
The sustainable evaluation of the lead acid batteries recycling process helps to quantitatively analyse the true value of resources, the environment and the economy, and provides recommendations for improving process sustainability. However, the environmental impact of pollutants hasn't been considered in the traditional emergy indicators. To this end, an improved emergy analysis method is proposed to evaluate the efficiency and sustainability of the lead acid batteries recovery process system. Firstly, the ecological effects of pollutant emissions are converted to equivalent waste emergy using the dilution method, the eco-indicator 99 method and the land erosion method. Then, the waste emergy and product emergy are included in the emergy index system, and improved emergy indices are put forward. In addition, in order to assess the system's resource recovery rate and clean production level, technical efficiency and environmental performance indicators have been increased. Finally, according to the evaluation results of emergy indicators, provide improvement measures for the optimisation system. To verify the feasibility of the proposed method, a sustainable evaluation of the recycling process system is applied. And the results show that pollutant emissions reduce the effectiveness and sustainability of the system. This method more truly reflects the overall performance of the system, compared with the traditional emergy method. The proposed method can be utilized as an effective tool for sustainable evaluation and optimisation of lead acid batteries recovery process system. Keywords: used lead acid batteries; sustainability evaluation; optimization; emergy analysis; cutting separation process
\end{abstract}

\section{Introduction}

Lead acid batteries (LABs) have many advantages, such as low cost of resources and manufacturing, superior high and low-temperature performance, safe and reliable 
operation, relatively mature recovery technology (Chang et al., 2009; Treptow and Richard, 2002). They are widely used in transportation, communications, power and other vital areas of the national economy. As the most important application area of lead, the use of LABs exceeds $80 \%$ of global lead production (Tian et al., 2018). In 2017, China produced about 3.8 million tons of LABs, more than $40 \%$ of the world's total output. In 2014, China recycled about 2.46 million tons of secondary lead from waste LABs (Sun et al., 2017).With the abandonment of LABs year by year, spent LABs have become a vast renewable lead resource. The lead content in batteries is over $60 \%$, which has high toxicity. Hence, active recovery and utilization of LAB is an efficient path to save resources, delay consumption speed. And it is also an essential means to improve material utilization efficiency and reduce environmental pollution (Battaïa et al., 2018). For the sake of realizing the sustainable and healthy development of spent LABs recycling enterprises, it is necessary not only to propose high technical requirement but also to evaluate the sustainability of spent LABs recycling companies from a systematic perspective. The purpose of the evaluation is to quantitatively analyse the real value of resources, environments and economic activities as well as the relationship between them, and provide theoretical basis and constructive suggestions on achieving cleaner production and sustainable development.Over the past few decades, scholars have put forwarded various methods to evaluate the influent of economy and environment for diverse systems, including life cycle assessment (LCA) (Liu, Wei et al., 2015), environmental risk assessment (Voelker et al., 2015), material flow analysis (Lu et al., 2016), emergy accounting(Almeida et al., 2018), exergy analysis(Bühler et al., 2018), ecological performance(Jiang et al., 2019), as well as energy analysis (Sandouqa and Al-Hamamre et al., 2019). Compared with other evaluation models, the emergy analysis method has obvious advantage. It can convert all kinds of different types of energy, 
resources, products, even labour and services into a unified dimension-solar emergy, so that all resources can be compared. It can objectively evaluate non-market inputs and make up for the lack of economic analysis, which provides a new idea for the calculation of environmental load and the evaluation of environmental economic performance (Liu and Yang, 2018). Based on the principles of energy and ecothermodynamics, the method is more convincing in reflecting the real value of natural resources and ecological services. And its detailed analysis of material flow and energy transfer makes it an essential tool for system analysis and evaluation.

Emergy theory has been established for more than 20 years. Its research fields include eco-economic systems of different scales, such as urban or regional ecosystems (Campbell and Garmestani, 2012; Liu, Gengyuan et al., 2015), agricultural ecosystems (Rydberg and Haden, 2006; Wu et al., 2015), eco-industrial parks (Pan et al., 2016a; Fang et al., 2017), industrial systems (Pan et al., 2016b; Santagata et al., 2019) and so on. However, there are few studies on the sustainability of waste LABs recovery systems based on emergy. Pan et al. (2019) evaluate the three subsystems of spent LABs recycling separately by the emergy analysis method. Only the ecological service and emission impact of air pollutants were quantified, and the emergy accounting was carried out by traditional emergy analysis method. The spent LABs recovery process system consumes plenty of exhaustible resources and produces a large number of pollutants such as waste gas, wastewater and solid waste. Thus, it is necessary to consider the impact of wastewater and solid waste on the ecological environment. Also, it is needed to convert the effects of waste emissions into equivalent emergy, to evaluate the sustainability of waste LABs recovery system comprehensively.

Therefore, in this study, the environmental impact of waste flow is included in the accounting system, and an improved emergy indicator system is proposed. The method 
is used to evaluate the overall impact of the production process of spent LABs recycling enterprises, including disassembly, sorting and various separation materials processing processes. Different from the traditional emergy indices, the improved emergy indicators take into account the system's waste emergy and product emergy. Moreover, according to the characteristics of the recycling system, technical and environmental efficiency indicators are added, and the system's resource recovery rate and clean production level are evaluated. The improved emergy method and the optimisation measure provide a more comprehensive and practical method for improving the sustainability of the spent LABs recovery process system.

\section{Methods}

\subsection{Scope and boundary}

In the recovery system of spent LABs, the input is waste LABs, raw materials and fuels, energy, labour, services and renewable resources. The output is waste $\left(E_{w}\right)$ and products $\left(\mathrm{E}_{\mathrm{r}}\right)$. The difference in the sustainability of the system is caused by factors such as production management, operation, process and technology, which leads to different characteristics of resource consumption and waste discharge. According to the features of waste LABs recovery system, the emergy flow system diagram can be drawn, as shown in Fig 1. 

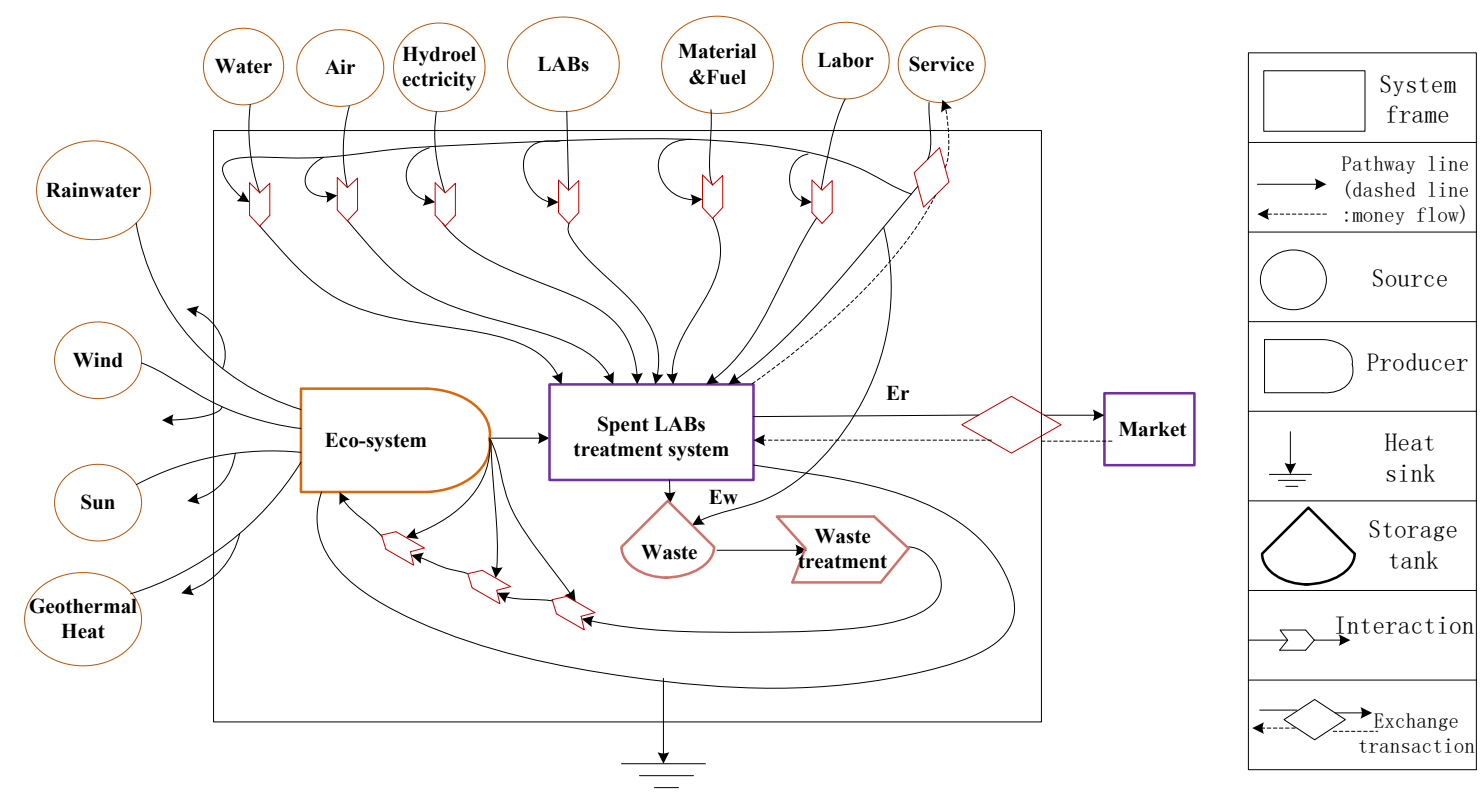

Fig. 1. Emergy flow chart of waste LABs recycling system.

\subsection{Process of emergy-based sustainability assessment}

The sustainability of waste LABs recovery system includes the benefits in economy, society and environment. Aiming at the boundary of spent LABs recovery system, we calculate the emergy loss of spent gas, wastewater and waste residue on ecosystem along with human health. These emergy losses are equivalent to the equivalent waste emergy, which is expressed as the emergy investment in waste disposal (Yang et al., 2003), and regarded as input from the economic system. On this basis, the sustainability index system of waste LABs recovery system was established. Thus, the sustainability of spent LABs recovery system can be quantitatively assessed. And the decision for optimizing the recovery process of waste LABs can be supplied as shown in Fig 2. 


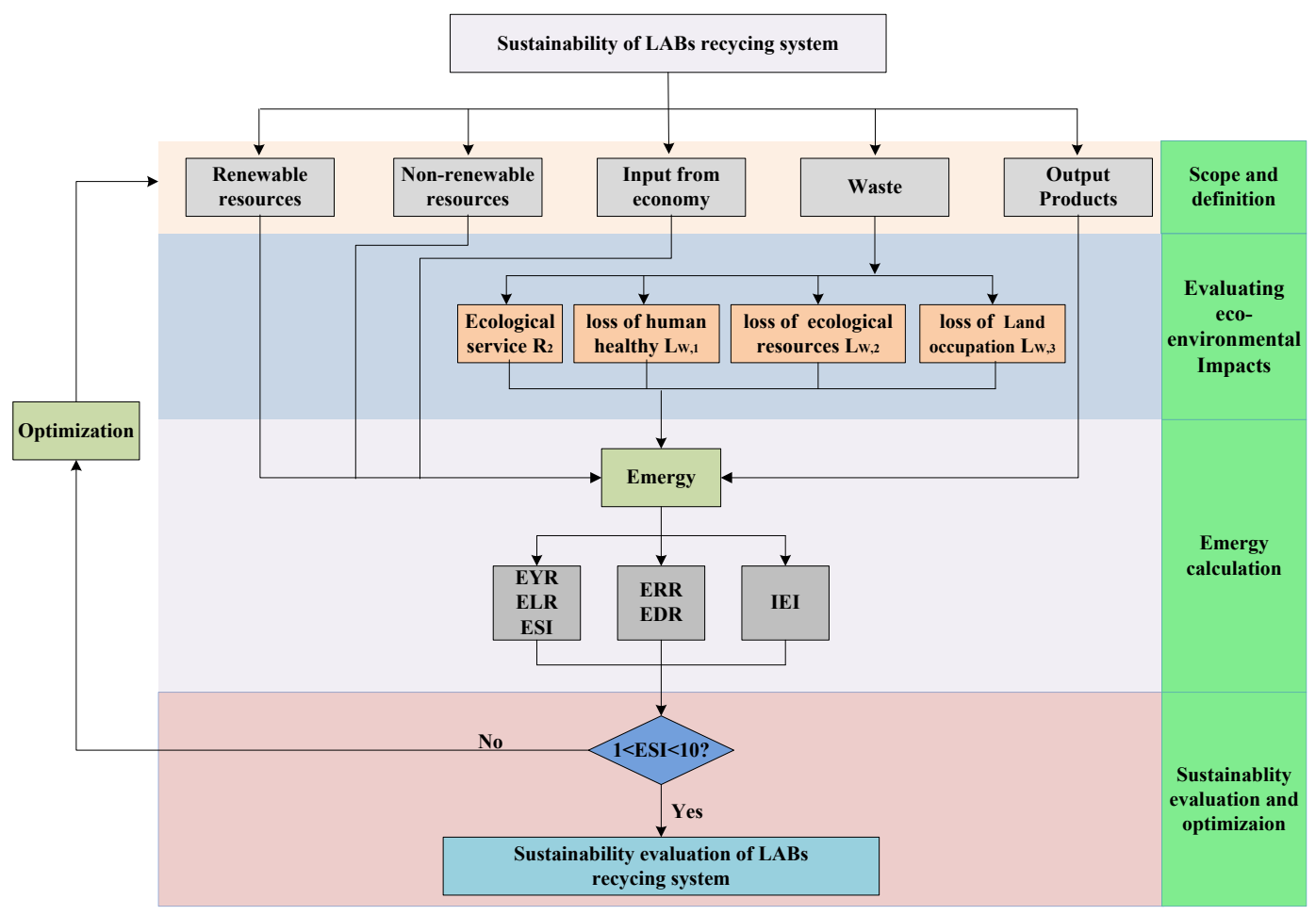

Fig 2. Process of emergy based sustainability evaluation.

\subsection{Assessment of the eco-environmental impact}

Evidence in recent decades has been demonstrated that human production and metabolic consumption activities have adverse temporal and spatial effects on human blessedness and ecosystem (Henry, 2005). Due to the rapid development of industry, environmental degradation and natural resource consumption have accelerated. And people have to start worrying about whether the balance between human and nature can be maintained. For the sake of balancing the sustainability of economy and environment, it is necessary to quantify the loss of pollutants to the economic system and ecosystem, facilitate the implementation of environmental protection strategies, and ensure the healthy development of industrial systems (Cai et al., 2019).

\subsubsection{Quantification of ecological services}

Waste LABs recycling process produces waste emissions. The air and water in nature will provide dilution, desalination or decomposition services that allow pollutant 
concentrations to reach an acceptable ecosystem range. According to Ulgiati and Brown (2002), the eco-services for calculating dilute air and water pollution are as follows:

$$
M_{\text {air } / \text { water }}=\rho * \frac{M}{C}
$$

Where $M_{\text {air/water }}$ indicates the amount of air/water needed for dilution. $\rho$ is the density of air/water (air density is $1.293 \mathrm{~kg} / \mathrm{m}^{3}$. water density is $1.0 \mathrm{E}+3 \mathrm{~kg} / \mathrm{m}^{3}$ ). $M$ is the i pollutant emission per year. $C$ is the tolerable concentration of pollutants confirmed by legislations.

$$
\begin{aligned}
& R_{W, \text { air }}=E_{W, \text { air }} * T r_{\text {air }}=1 / 2 * M_{\text {air }} * v^{2} * T r_{\text {air }} \\
& R_{W, \text { water }}=E_{W, \text { water }} * T r_{\text {water }}=M_{\text {water }} * G * T r_{\text {water }} \\
& R_{W}=\operatorname{Max}\left(R_{W, \text { air }, i}\right)+\operatorname{Max}\left(R_{w, \text { water }, i}\right)
\end{aligned}
$$

Where $R_{w}$ is the eco-services emergy required for dilution of air/water pollutants. $E_{w}$ is the energy of motion for dilute air or the available chemical energy of water. $\operatorname{Tr}$ is the emergy conversion rate of wind/water $(7.90 \mathrm{E}+2 \mathrm{sej} / \mathrm{J}$ [NEAD, 2014] for wind, $7.01 \mathrm{E}+3 \mathrm{sej} / \mathrm{J}[\mathrm{NEAD}, 2014]$ for water). $v$ is mean wind speed per year; and $G$ is Gibbs free energy per unit of water relative to seawater (4.94E+3J/kg [Liu and Yang, 2018]). $R_{w}$ is the sum of the maximum eco-service emergy required for dilution of air and water pollutants.

\subsubsection{Quantification of pollutant emissions' impact}

It is necessary to quantify the actual damage value of natural and human capital with the real emission value, because of the adverse effects such as ecosystem degradation or human health damage caused by pollutant emissions. According to the Eco-indicator 99 evaluation method of Goedkoop and Spriensma (2000), to reflect the loss of natural capital, this paper introduces PDF (Potentially Disappeared Fraction of species) method. To reflect people's concern about the damage caused by pollution and to measure the 
degree of damage, this paper introduces the DALY (Disability Adjusted Life Years) method, which affects human health due to contamination.

Pollutant emissions have adverse effects on social health, requiring extra resources. The formula for calculating human health emergy damages can be expressed as follows:

$$
L_{w, l}=\sum m_{i} * D A L Y_{i} * \tau_{H}
$$

Where, $L_{w, 1}$ is the emergy loss of the affected population; $i$ represents the type $i$ pollutant; $m$ is the quality of the chemical substances released from the pollutants. $D A L Y$ is its impact factor in the evaluation framework of Eco-indicator $99 \cdot \tau_{H}=$ total regional emergy/total population.

The formula for calculating emergy loss of ecological resources is as follows:

$$
L_{w, 2}=\sum m_{i} * \operatorname{PDF}(\%)_{i} * E_{B i o}
$$

Where, $L_{w, 2}$ is the loss of the affected natural resources; $m_{i}$ has the same meaning as $m_{i}$ in formula 5; $P D F(\%)$ is the potential extinction ratio, in unit $P D F \cdot \mathrm{m}^{2} \cdot a / \mathrm{kg} \cdot E_{B i o}$ is the emergy of unit biological resources $[\operatorname{sej} /(M \bullet a)]$.It can be calculated by the emergy of local wasteland natural resources, agricultural resources, forestry resources, animal husbandry resources and fishery production.

The waste LABs recycling system produces a large number of solid waste, such as lead slag, lead-containing dust collection, lead-containing sludge, waste activated carbon, domestic waste, and so on. Lead slag and waste activated carbon are handed over to qualified treatment units, usually without landfill treatment. Lead-containing dust collection and lead-containing sludge are reused for production, while domestic waste is sent to the garbage dump. For solid wastes disposed of at landfills, the land area will be occupied. The environmental losses caused by this treatment can be calculated by the land area occupied by it (Reza et al., 2014):

$$
L_{\mathrm{w}, 3}=\sum \mathrm{m}_{\mathrm{i}} * L_{\mathrm{oc}} * \mathrm{E}_{\mathrm{L}}
$$


Where, $L_{w, 3}$ is the emergy loss resulted by solid waste discharge. $m$ represents the discharge amount of solid waste. $L_{o c}$ represents the impact of solid waste, that is, the land area occupied by each ton of solid waste. Relevant research results show that $2.85 \mathrm{E}+4 \mathrm{t}$ industrial waste occupies $l \mathrm{hm}^{2}$ land, $E_{L}$ is the emergy conversion rate of land erosion. According to the average emergy of land erosion, the conversion rate of emergy is $1.33 \mathrm{E}+15 \mathrm{sej} / \mathrm{hm}^{2}$ (Shen et al., 2019).

\subsection{Emergy indices}

Emergy method is first used to study natural ecosystems. In natural ecosystems, the renewability of waste is usually not considered, because garbage may be the resource input for the next metabolic process. However, in industrial systems, there is no procedure of waste disposal, and the environmental and economic impacts of different waste disposal methods are also different. Therefore, for the sake of correctly evaluating the sustainability of industrial systems, it is necessary to incorporate waste emergy into emergy accounting and improve the traditional emergy indicators.

\subsubsection{Improved emergy indices}

The solid waste in this study system is not landfilled treatment, so the emergy loss of solid waste discharge $L_{w, 3}$ is not calculated. Based on the primary emergy accounting method (Odum, 1996; Brown and Ulgiati, 1997) and the quantitative method for the impact of pollutant discharge on the eco-environment, the emergy evaluation indices are revised. It is as shown in Table 1.

Table 1 Improved emergy indices.

\begin{tabular}{lll}
\hline Indices & Expression & Equation \\
\hline Basic definitions & Renewable resources & $\mathrm{R}$ \\
& Non-renewable resources & $\mathrm{N}$ \\
& Input from economy & $\mathrm{F}$ \\
& Ecological service needed to dilute & $\mathrm{R}_{2}$ \\
emissions & \\
Emergy loss of human healthy & $\mathrm{L}_{\mathrm{w}, 1}$
\end{tabular}




\begin{tabular}{lll} 
& $\begin{array}{l}\text { Emergy loss of ecological resources } \\
\text { Output emergy of system } \\
\text { End-of-life LABs emergy } \\
\text { Waste emergy }\end{array}$ & $\mathrm{L}_{\mathrm{w}, 2}$ \\
& & $\mathrm{Er}$ \\
& $\mathrm{E}_{\mathrm{LAB}}$ \\
& $\mathrm{E}_{\mathrm{w}}=\mathrm{R}_{2}+\mathrm{L}_{\mathrm{w}, 1}+\mathrm{L}_{\mathrm{w}, 2}$ \\
& $\mathrm{U}=\mathrm{R}+\mathrm{N}+\mathrm{F}$ & \\
\hline Total emergy & $\mathrm{EYR}=\mathrm{U} / \mathrm{F}$ & $\mathrm{U}_{\mathrm{i}}=\mathrm{R}+\mathrm{N}+\mathrm{F}+\mathrm{E}_{\mathrm{w}}$ \\
Emergy yield ratio & $\mathrm{ELR}=(\mathrm{N}+\mathrm{F}) / \mathrm{R}$ & $\mathrm{EYR}_{\mathrm{i}}=\mathrm{Er} /\left(\mathrm{F}+\mathrm{E}_{\mathrm{w}}\right)$ \\
Environmental Loading Ratio & $\mathrm{ELR}_{\mathrm{i}}=\left(\mathrm{N}+\mathrm{F}+\mathrm{E}_{\mathrm{w}}\right) / \mathrm{R}$ \\
Emergy sustainability index & $\mathrm{ESI}=\mathrm{EYR} / \mathrm{ELR}$ & $\mathrm{ESI}_{\mathrm{i}}=\mathrm{EYR} / \mathrm{ELR}$ \\
\hline
\end{tabular}

2.4.2 Other emergy indices

1. Technical efficiency indicators

The recovery rate of waste $\mathrm{LABs}$ is a significant target of the resource recovery system. To make up for the shortages of conventional emergy index, ERR and EDR are proposed.

(1)Emergy recovery ratio

$$
E R R=\frac{E_{r}}{E_{L A B}} \times 100 \%
$$

$E R R$ is the emergy ratio of recovered resources to spent LABs (Song et al., 2012).

(2)Emergy discarded ratio

$$
E D R=\frac{E_{W}}{(R+N+F)}
$$

$E D R$ represents the emergy ratio of waste $\left(E_{w}\right)$ to total system input for removal of waste emergy $(R+N+F)$. With the increase of EDR, the utilization rate and recovery efficiency of system resources decrease (Liu et al., 2018).

2. Environmental performance indicator

Intensity of emissions' impacts

$$
I E I=\frac{E_{W}}{G P V}
$$

According to Pan et al. (2018), IEI is the impact of discharge per unit of gross production value $(G P V)$ produced. The higher the index value, the higher the effect on 
public health and environment. In addition, the index indirectly measures the cleaner production level of industrial enterprises.

\subsection{Data collection}

Data acquisition and reliability are significant for evaluating and improving the sustainability of recovery systems. For different recycling processes, material, energy, services and waste emissions will also vary. This study needs a lot of primary data. These data are mainly from enterprise environmental impact assessment reports. The basic data of resource input are partly from local government reports. And the basic data of economic system input, output products and GPV come partly from enterprise statistical statements.

\section{Case study}

In this paper, a representative waste LABs recycling system, the crushing separation process system, is selected to proving the practicability of the evaluation model. Case study consists of three aspects: (1) background; (2) optimisation of process system based on emergy analysis; (3) results and discussions.

\subsection{Background}

The crushing separation process system (CX for short) studied in this paper takes Hubei Chukai Metallurgical Co., Ltd. as an example. The factory is situated in Laohekou City, Hubei, China, with an area of 73260 square meters. Annual disposal of 100,000 tons of spent LABs. The process flow chart is shown in Fig.3. 


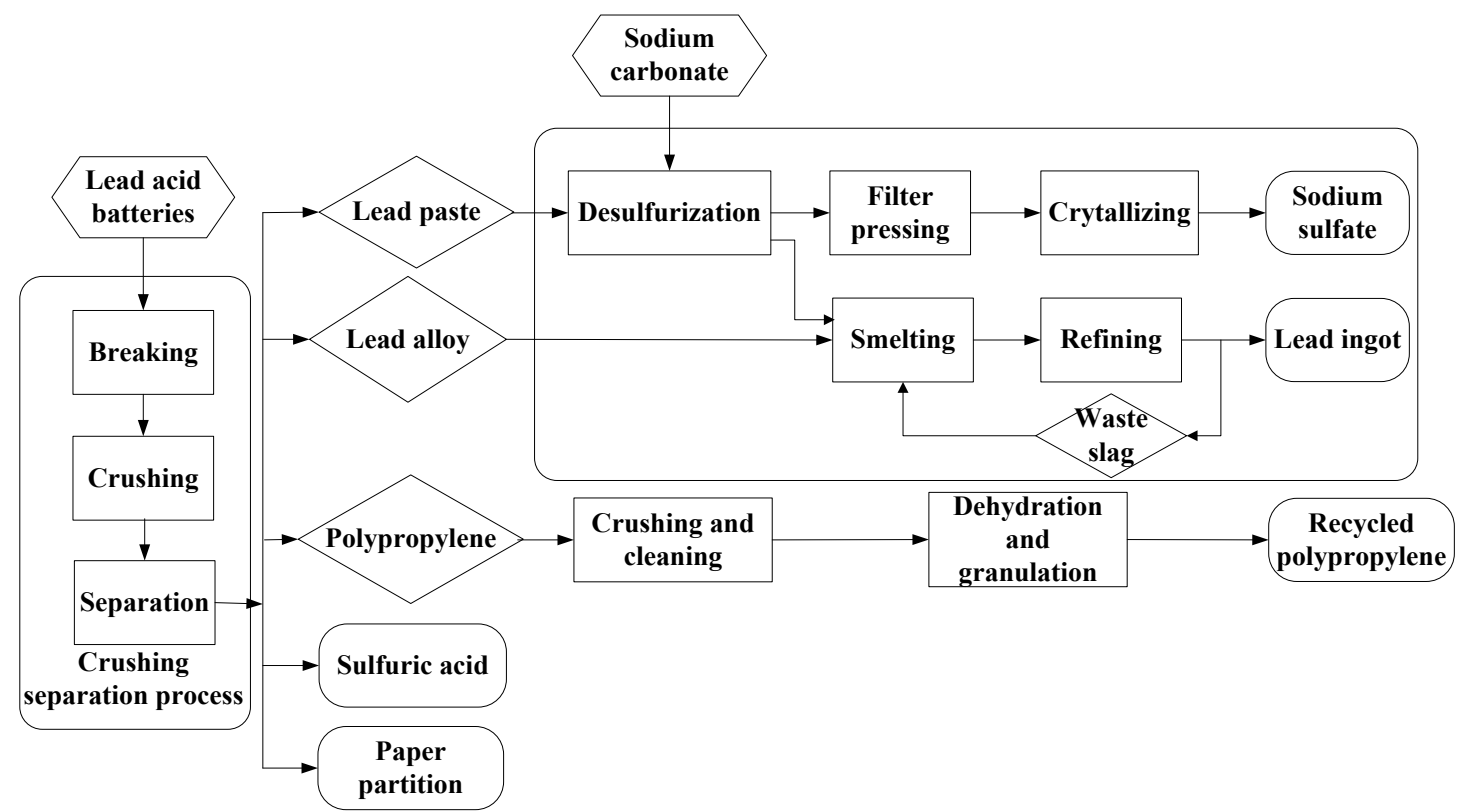

Fig.3. The craft chart of the crushing separation process.

3.2 Optimisation of process system based on emergy analysis

\subsubsection{Emergy-based accounting and emergy indicators of CX system}

Table A.1, A.2 and A.3 (Appendix) list the emergy accounting tables and waste emergy of CX system. Table 2 lists the emergy indices of CX system. According to Brown and Ulgiati (2016), the global emergy benchmark adopted in this study is $12.0 \mathrm{E}+24 \mathrm{sej} / \mathrm{yr}$.

Table 2 Emergy indices of CX system.

\begin{tabular}{lcc}
\hline Indices & Traditional emergy index & Improved emergy index \\
\hline U(sej/yr) & $6.23 \mathrm{E}+20$ & $6.25 \mathrm{E}+20$ \\
EYR & 75.26 & 55.06 \\
ELR & 58.05 & 58.25 \\
ESI & 1.30 & 0.95 \\
\hline Indices & \multicolumn{2}{c}{ Other emergy index } \\
\hline GPV(sej/yr & $1.62 \mathrm{E}+08$ \\
ERR & $121.55 \%$ \\
EDR & $0.35 \%$ \\
IEI & \multicolumn{3}{c}{$1.34 \mathrm{E}+10$} \\
\hline
\end{tabular}

3.2.1.1 Analysis of sustainability indicators (ESI)

ESI was used to measure the sustainability of the system. Ulgiati S. considers that 1 $<$ ESI $<10$ indicates the vitality and development potential of the economic system. 
ESI $>10$ is the symbol of economic underdevelopment, meaning inadequate exploitation and utilization of resources. And when ESI $<1$, it is a consumptionoriented financial system.

For CX system, the traditional index value (1.30) is higher than the improved index value (0.95). It is due to the waste disposal in CX system consumes a certain amount of workforce and material resources, resulting in the reduction of molecular EYR value of improved indicators. Since $0.95<1$, the system is a consumption-oriented economic system, and its sustainability needs to be improved.

\subsubsection{Analysis of other emergy indices}

To improve the sustainability of the system, we need to enhance technical efficiency and environmental performance indicators. According to the calculation formula (8-10), it is necessary to cut down the waste emergy $\mathrm{E}_{\mathrm{w}}$ and raise the output product emergy Er for improving the sustainability of $\mathrm{CX}$ system. After analysis, CX system can be improved from the following two aspects:

(1) Increase product revenue. That is to say, raising the kinds of disassembly materials and enhancing the separation degree of various materials.

When the lead-antimony alloy and the lead-calcium alloy are separated during disassembly, not only a kind of material is added, but also the separation degree of the lead alloy is improved. In addition, the price of lead-antimony alloy and lead-calcium alloy are much higher than that of lead alloy, which makes the profit of system products increase significantly. However, the existing disassembly process cannot meet the requirement of separating the two. We should make the waste batteries fine disassembly. The terminal post, the bus bar (made of lead-antimony alloy) and the grid (made of lead-calcium alloy) are separated. 
(2) Cut down waste emergy. If the disassembly process equipment carries out independent research and development, local breakdown instead of overall breakdown will reduce noise pollution and sulfuric acid mist. The gas collecting device is added to collect lead dust, dust and sulfuric acid mist and control of which, to cut down the emergy of waste.

\subsubsection{Improved process system}

According to the basic structure of spent LABs and the density of each component, the CX system was improved. The fine disassembly method was put forward, and the cutting separation process (CS for short) was designed. The process flow is shown in Fig.4. The cutting separation method is as follows: After precisely cutting the root of the bus bar of each battery, the upper cover and the lower half of the battery are separated. The lower half of the battery is turned over 180 degrees, and waste sulfuric acid is poured out, then continuous vibration is carried out to separate the shell and plate group. Then the four components (upper cover, waste sulfuric acid, plate group and shell) are collected respectively. And six materials are separated according to the density and particle size of each material.

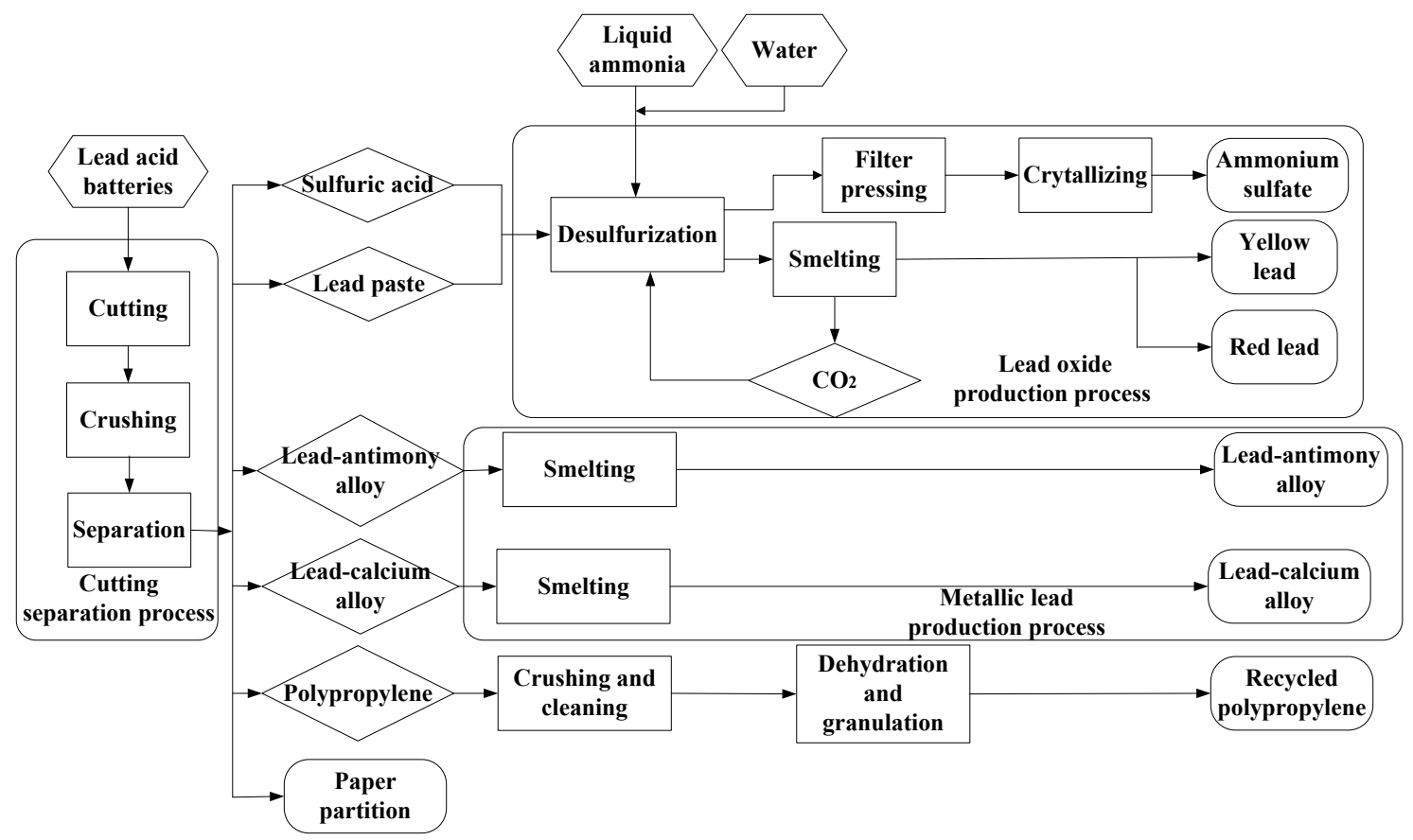


Fig.4. The craft chart of the cutting separation process.

CS system takes Guizhou Cenxiang Resources Science and Technology Co., Ltd. as an example. The factory is located in Cenggong Economic Development Zone, Guizhou Province, China. Besides, it covers an area of 33,000 square meters and handles 200,000 tons of waste LABs annually. Next, the emergy analysis of the improved CS system is implemented, and emergy accounting and emergy indicators of CX system and CS system are discussed.

\subsection{Results and discussions}

\subsubsection{Emergy accounting}

Table B.1, B.2 and B.3 (Appendix) respectively listed emergy accounting tables for CS system.

1. Renewable and non-renewable resources

The ratio of the emergy input of the two systems to the total emergy input is very low (less than $2 \%$ ), mainly due to the high emergy of waste LABs, accounting for $75.97 \%$ and $94.43 \%$ of the total emergy input. They are the most important non-renewable resources. Compared with natural systems, the spent LABs recycling system uses few renewable natural resources, which is a technology-intensive industrial system.

2. Emergy input from economic system

In this study, the input from economic systems includes labour input, depreciation cost of production equipment, maintenance cost, depreciation cost of environmental protection equipment and treatment cost. The depreciation cost of equipment is converted to 20 years, and the maintenance cost is calculated to $2.5 \%$ of the purchase cost of equipment. The cost of environmental protection treatment mainly includes the cost of "three wastes" treatment and the cost of maintenance and operation. The emergy input of depreciation cost of environmental protection equipment and treatment cost 
accounts for $25.16 \%$ (CX system) and $35.21 \%$ (CS system) of emergy input from economic systems. Compared with CX system, CS system enlarges environmental protection emergy input from economic systems.

\section{Waste emergy}

According to the tables, the total emergy of waste is $2.17 \mathrm{E}+18 \mathrm{sej} / \mathrm{yr}(\mathrm{CX}$ system) and $1.09 \mathrm{E}+18 \mathrm{sej} / \mathrm{yr}$ (CS system). Although the scale of waste batteries treated by CS system is twice as large as that of CX system, the total waste emergy is less than half. It shows that the CS system has less pollution to the ecological environment, and the clean production capacity is significantly improved. This is also related to the increase of environmental protection emergy input from the economic system. In this research systems, ammonia nitrogen is the pollutant with the largest ecological service emergy. Lead dust has a carcinogenic effect on human health and contributes $78.18 \%(\mathrm{CX}$ system) and $47.02 \%$ (CS system) to emergy loss, respectively. Firms need to strengthen pollution control of ammonia nitrogen and lead dust to provide strategies for achieving cleaner production.4. Output products emergy

The UEV of lead ingot is $8.73 \mathrm{E}+15 \mathrm{sej} / \mathrm{t}$, that of lead-antimony alloy is $9.99 \mathrm{E}+15 \mathrm{sej} / \mathrm{t}$, and that of lead-calcium alloy and lead oxide is $1.05 \mathrm{E}+16 \mathrm{sej} / \mathrm{t}$ in the study. According to Brown and Ulgiati (2010), the UEV recalculated from the global sediment update baseline was $2.13 \mathrm{E}+17 \mathrm{seJ} / \mathrm{t}$. The $\mathrm{UEV}$ of recycled lead is ten times smaller than that of primary lead mines. This show that the recovery industry of spent LABs has higher renewable efficiency than that of the low-efficiency and seriously polluted lead mining industry. 


\subsubsection{Emergy indices}

Table 3 lists the emergy indices of the two systems. These emergy indicators are analysed and discussed to assess the enterprises' environmental performance and sustainability.

Table 3 Emergy indices of CX system and CS system.

\begin{tabular}{lcccc}
\hline Indices & \multicolumn{2}{c}{ Traditional emergy index } & \multicolumn{2}{c}{ Improved emergy index } \\
\cline { 2 - 5 } & CX system & CS system & CX system & CS system \\
\hline Total emergy U & $6.23 \mathrm{E}+20$ & $1.00 \mathrm{E}+21$ & $6.25 \mathrm{E}+20$ & $1.00 \mathrm{E}+21$ \\
Emergy yield ratio EYR & 75.26 & 175.93 & 55.06 & 218.63 \\
Environmental Loading Ratio ELR & 58.05 & 62.10 & 58.25 & 62.17 \\
Emergy sustainability index ESI & 1.30 & 2.83 & 0.95 & 3.52 \\
\hline Indices & \multicolumn{2}{c}{ CX system } & CS system \\
\hline GPV & $1.62 \mathrm{E}+08$ & $4.18 \mathrm{E}+08$ \\
ERR & $121.55 \%$ & $156.87 \%$ \\
EDR & $0.35 \%$ & $0.11 \%$ \\
IEI & $1.34 \mathrm{E}+10$ & $2.62 \mathrm{E}+09$ \\
\hline
\end{tabular}

1. Improved emergy indices

(1) Emergy Yield Ratio (EYR)

According to the definition of H.T.Odum, EYR is equal to the emergy ratio of system output to input from economic systems. The system output emergy is expressed by the product emergy rather than the total input emergy. EYR reflects the contribution of the production of enterprises' eco-economic systems to the economy and the ecoeconomic efficiency of the system.

Compared with the traditional EYR, the improvement index of the CX system is reduced, which shows that the waste disposal consumes a certain amount of workforce and material resources. The improvement index of the CS system is increased, which shows that although the waste disposal consumes a certain amount of workforce and material resources, the enterprise has strong competitiveness and high total output emergy. According to EYR value, CS system has strong competitiveness and top economic benefits. 
In this study, EYR were higher than those of electronic waste recycling companies (15.10, 2.72; Song et al., 2012, 2013) and end of life automobile recycling enterprises (23.54, Pan and Li, 2016).It shows that enterprises have significant competitiveness and high economic efficiency.

\section{(2)Environmental Loading Ratio (ELR)}

According to the definition of H.T.Odum, ELR is equal to the emergy ratio of input of economic systems to renewable resources. It is an index to measure the utilization of environmental services in production systems. The more ecological services used in the system operation is, the less pressure on the environment is, the less ELR is. In this study, the ELR value is much higher than 10, indicating that the environmental load of both systems is very high. The main reason is that the proportion of non-renewable resources in industrial systems is large (more than 96.00\%). Compared with the traditional indicators, the improvement indicators of the two systems are smaller and slightly higher. This shows that the waste emergy of the two systems are small compared to non-renewable resources.

(3) Emergy sustainable index (ESI)

Compared with the traditional ESI, the improved index of the CX system is degraded. This shows that in the process of waste disposal, a certain amount of manpower and material resources are consumed, resulting in a decline in system sustainability. However, this reflects the fact that the CX system produces a lot of waste, and it is necessary to use a revised index. The improved index of the CS system is increased compared to the conventional ESI. This is because although the disposal of waste in the CS system consumes a certain amount of manpower and material resources, the total output emergy of the system is high, resulting in an increase in the molecular 
EYR value. Compared with the CX system, the ESI value of the CS system is large, indicating that the system has higher sustainability and more development potential.

2. Other emergy indices

(1) Emergy recovery ratio (ERR)

ERR reflects the ability of a system to recover energy and materials from. The ERR values of the CX system and the CS system are $121.55 \%$ and $156.87 \%$, respectively. It shows that the CS system has a larger recovery emergy value, a high technical level and a high operating efficiency.

The ERR value of both systems are higher than that of the electronic waste recovery enterprise (28.05\%, Song et al., 2012) and scrap automobile recycling enterprise (30.08\%, Pan and Li, 2016).This reflects the significant recyclability and high level of skill of these two systems.

(2) Emergy discarded ratio (EDR)

EDR demonstrates the level of utilization and recovery of system resources. The EDR values of CX system and CS system are $0.35 \%$ and $0.11 \%$, respectively, which are much lower than those of manufacturing system $(6.46 \%$, Liu et al., 2018). It shows that the resource utilization level and recovery degree of this research systems are higher.

(3)Intensity of emission impact (IEI)

The IEI values of CX system and CS system are $1.34 \mathrm{E}+10 \mathrm{sej} / \$$ and $2.62 \mathrm{E}+09 \mathrm{sej} / \$$, respectively. It shows that for every dollar of economic output, each system will have an impact on $1.34 \mathrm{E}+10$ sej and $2.62 \mathrm{E}+09$ sej for public health and local ecosystems. The IEI values of the two systems are much lower than that of spent LABs recycling enterprises $(5.60 \mathrm{E}+10 \mathrm{sej} / \$$, Pan et al., 2019). It indicates that the impact of the research systems on eco-environment is low. However, due to the severe effects of lead on the 
environment, the management of lead emissions still needs to be given priority attention. Besides, the IEI value of the CS system is much lower than that of the CX system. It indicates that the CS system has a lower impact on eco-environment, and indirectly measures the higher level of cleaner production.

In this paper, an improved energy value analysis method is proposed. Compared with the traditional emergy indicators, the EYR and ESI are lower and the ELR are increasing. However, with the improved cutting separation process (CS system), the output product emergy is higher than the total input emergy, resulting in higher EYR, ELR and ESI than the traditional indicators. The results show that the economic, environmental efficiency and sustainability of the CS system is better than the CX system. The improved emergy analysis method can reflect the actual characteristics of the recycling system more truly and comprehensively.4. Conclusions

Sustainability evaluation is of great significance to realize the economic and environmental performance of enterprises and promote the sustainable development of the entire used LABs recycling industry. In this study, a sustainable evaluation model based on emergy is established. Different from the traditional emergy indicator system, the model incorporates waste emergy and product emergy into the emergy indicator system. The dilution effect, the eco-indicator 99 method and the land erosion method are used to convert the emission impact into an equivalent waste emergy. Finally, combined with the evaluation results, a fine disassembly method-cutting and sorting process is proposed to optimise the efficiency and sustainability of the recovery system.

The sustainable evaluation of the CX system and the CS system clearly demonstrates that the proposed method meets the objectives of this research and is feasible. In addition, improved emergy indicators can more realistically reflect the system's resource, environmental, economic, and technical efficiency. The emergy indicator system can also be established according to specific characteristics of different 
systems. In order to improve the sustainability of recycling companies, optimise recycling processes, implement cleaner production, reduce non-renewable resources or increase the use of renewable resources, it is an effective measure.

However, this study also has its limitation. Since the UEV of some items have no reference value, they are replaced by the 2014 National Emergy Money Ratio (EMR, the value was updated according to GEB2016), which may cause uncertainty in the results. Future research should use more accurate UEV values to overcome this problem. Moreover, in the future, the interaction between lead-acid battery manufacturers and recycling enterprises should be analysed to promote the sustainable development of lead-acid battery resources.

\section{Acknowledgments}

This work was supported by the Key Special Project of 'Solid Waste Recycling' of National Key Research and Development Program [grant No. 2018YFC1902400], the Major Technical Innovation Program of Hubei Province [grant No. 2017ACA180], and the National Natural Science Foundation of China (51675388). We are also grateful for the support of the Plateau Disciplines in Shanghai, and Hubei Chukai Metallurgical Co., Ltd and Guizhou Cenxiang Resources Science and Technology Co., Ltd.

\section{Appendix. Further details about data and calculation process.}

Table A. 1

Emergy analysis table of the crushing separation process.

\begin{tabular}{|c|c|c|c|c|c|c|}
\hline Items & Units & Raw data & $\begin{array}{l}\text { UEV(sej/uni } \\
\text { t) }\end{array}$ & Reference & $\begin{array}{l}\text { Emergy(s } \\
\text { ej/yr) }\end{array}$ & $\begin{array}{l}\text { Percent of } \\
\text { item(\%) }\end{array}$ \\
\hline \multicolumn{5}{|c|}{ Total inputs(sum of 1-17) } & $6.23 E+20$ & $100 \%$ \\
\hline \multicolumn{5}{|c|}{ Renewable Resources(R)(Sum of 1-7) } & $1.05 E+19$ & $1.69 \%$ \\
\hline 1.Sun & $\mathrm{J} / \mathrm{yr}$ & $3.13 \mathrm{E}+14$ & 1 & By definition & $3.13 \mathrm{E}+14$ & $0.00 \%$ \\
\hline 2.Wind & $\mathrm{J} / \mathrm{yr}$ & $6.19 \mathrm{E}+10$ & $7.90 \mathrm{E}+02$ & NEAD, 2014 & $4.89 \mathrm{E}+13$ & $0.00 \%$ \\
\hline 3. Geothermal Heat & $\mathrm{J} / \mathrm{yr}$ & $9.85 \mathrm{E}+09$ & $4.90 \mathrm{E}+03$ & NEAD, 2014 & $4.83 \mathrm{E}+13$ & $0.00 \%$ \\
\hline 4.Rainwater & $\mathrm{J} / \mathrm{yr}$ & $2.15 \mathrm{E}+11$ & $7.01 \mathrm{E}+03$ & NEAD, 2014 & $1.51 \mathrm{E}+15$ & $0.00 \%$ \\
\hline 5.Air & $\mathrm{t} / \mathrm{yr}$ & $7.91 \mathrm{E}+04$ & $3.91 \mathrm{E}+13$ & Wang et al., 2005 & $3.10 \mathrm{E}+18$ & $0.50 \%$ \\
\hline 6. Water & $\mathrm{t} / \mathrm{yr}$ & $6.29 \mathrm{E}+04$ & $5.03 \mathrm{E}+11$ & Wang et al., 2005 & $3.17 \mathrm{E}+16$ & $0.01 \%$ \\
\hline
\end{tabular}




\begin{tabular}{|c|c|c|c|c|c|c|}
\hline \multirow{2}{*}{\multicolumn{3}{|c|}{$\begin{array}{lcr}\text { 7.Electricity } \quad \mathrm{J} / \mathrm{yr} & 2.12 \mathrm{E}+13 \\
\text { Nonrenewable Resources(N) (Sum of 8-12) }\end{array}$}} & \multirow[t]{2}{*}{$3.50 \mathrm{E}+05$} & \multirow[t]{2}{*}{ NEAD, 2014} & \multirow{2}{*}{$\begin{array}{l}7.42 \mathrm{E}+18 \\
\mathbf{6 . 0 4 E}+\mathbf{2 0}\end{array}$} & \multirow{2}{*}{$\begin{array}{r}1.19 \% \\
\mathbf{9 6 . 9 8 \%}\end{array}$} \\
\hline & & & & & & \\
\hline 8.LABs & $\$ / y r$ & $1.33 \mathrm{E}+08$ & $3.55 \mathrm{E}+12$ & NEAD, 2014 & $4.73 \mathrm{E}+20$ & $75.97 \%$ \\
\hline 9. Sodium carbonate & $\mathrm{t} / \mathrm{yr}$ & $5.64 \mathrm{E}+03$ & $1.27 \mathrm{E}+15$ & Liu and Yang, 2018 & $7.18 \mathrm{E}+18$ & $1.15 \%$ \\
\hline 10.Scrap iron & $\mathrm{t} / \mathrm{yr}$ & $1.02 \mathrm{E}+03$ & $2.70 \mathrm{E}+15$ & Santagata et al., 2019 & $2.75 \mathrm{E}+18$ & $0.44 \%$ \\
\hline 11.Flux (coke) & $\mathrm{t} / \mathrm{yr}$ & $2.10 \mathrm{E}+03$ & $4.31 \mathrm{E}+16$ & Liu and Yang, 2018 & $9.05 \mathrm{E}+19$ & $14.53 \%$ \\
\hline 12.Natural gas & $\mathrm{J} / \mathrm{yr}$ & $2.17 \mathrm{E}+14$ & $1.40 \mathrm{E}+05$ & NEAD, 2014 & $3.04 \mathrm{E}+19$ & $4.88 \%$ \\
\hline \multicolumn{5}{|c|}{ Input from economy(F) (Sum of 13-17) } & $8.28 E+18$ & $1.33 \%$ \\
\hline 13.Staffs salaries & $\$ / y r$ & $4.12 \mathrm{E}+05$ & $3.55 \mathrm{E}+12$ & NEAD, 2014 & $1.46 \mathrm{E}+18$ & $0.23 \%$ \\
\hline 14.Equipment & $\$ / y r$ & $8.89 \mathrm{E}+05$ & $3.55 \mathrm{E}+12$ & NEAD, 2014 & $3.15 \mathrm{E}+18$ & $0.51 \%$ \\
\hline 15.Equipment & $\$ / y r$ & $4.44 \mathrm{E}+05$ & $3.55 \mathrm{E}+12$ & NEAD, 2014 & $1.58 \mathrm{E}+18$ & $0.25 \%$ \\
\hline 16.Environmental & $\$ / y r$ & $1.27 \mathrm{E}+05$ & $3.55 \mathrm{E}+12$ & NEAD, 2014 & $4.52 \mathrm{E}+17$ & $0.07 \%$ \\
\hline 17.Environmental & $\$ / y r$ & $4.59 \mathrm{E}+05$ & $3.55 \mathrm{E}+12$ & NEAD, 2014 & $1.63 \mathrm{E}+18$ & $0.26 \%$ \\
\hline \multicolumn{5}{|c|}{ Outputs(sum of 18-21) } & $5.75 E+20$ & $100 \%$ \\
\hline 18.Lead ingot & $\$ / y r$ & $1.49 \mathrm{E}+08$ & $3.55 \mathrm{E}+12$ & NEAD, 2014 & $5.31 \mathrm{E}+20$ & $92.25 \%$ \\
\hline 19.Sulfuric acid & $\mathrm{t} / \mathrm{yr}$ & $6.00 \mathrm{E}+03$ & $5.04 \mathrm{E}+15$ & Nimmanterdwong et al., 2015 & $3.02 \mathrm{E}+19$ & $5.25 \%$ \\
\hline 20.Plastic & $\mathrm{t} / \mathrm{yr}$ & $5.00 \mathrm{E}+03$ & $2.40 \mathrm{E}+15$ & Brown and Ulgiati, 2004 & $1.20 \mathrm{E}+19$ & $2.09 \%$ \\
\hline 21.Sodium sulfate & $\$ / y r$ & $6.66 \mathrm{E}+05$ & $3.55 \mathrm{E}+12$ & NEAD, 2014 & $2.37 \mathrm{E}+18$ & $0.41 \%$ \\
\hline \multicolumn{7}{|l|}{ Waste(sum of 22-24) } \\
\hline \multicolumn{7}{|l|}{ 22.Air pollutants } \\
\hline Fumes & $\mathrm{kg} / \mathrm{yr}$ & $2.70 \mathrm{E}+03$ & & & & \\
\hline $\mathrm{SO}_{2}$ & $\mathrm{~kg} / \mathrm{yr}$ & $3.16 \mathrm{E}+04$ & & & & \\
\hline Lead dust & $\mathrm{kg} / \mathrm{yr}$ & $7.78 \mathrm{E}+01$ & & & & \\
\hline Sulfuric acid & $\mathrm{kg} / \mathrm{yr}$ & $4.40 \mathrm{E}+03$ & & & & \\
\hline NMHC & $\mathrm{kg} / \mathrm{yr}$ & $7.05 \mathrm{E}+02$ & & & & \\
\hline \multicolumn{7}{|l|}{ 23. Water pollutants } \\
\hline COD & $\mathrm{kg} / \mathrm{yr}$ & $3.67 \mathrm{E}+02$ & & & & \\
\hline $\mathrm{NH}_{3}-\mathrm{N}$ & $\mathrm{kg} / \mathrm{yr}$ & $5.56 \mathrm{E}+01$ & & & & \\
\hline \multicolumn{7}{|l|}{ 24.Solid pollutants } \\
\hline Paper partition & $\mathrm{kg} / \mathrm{yr}$ & $7.00 \mathrm{E}+06$ & & & & \\
\hline Lead slag & $\mathrm{kg} / \mathrm{yr}$ & $4.00 \mathrm{E}+06$ & & & & \\
\hline Other waste & $\mathrm{kg} / \mathrm{yr}$ & $3.20 \mathrm{E}+03$ & & & & \\
\hline
\end{tabular}

1. Solar energy $(\mathrm{J})=($ Land area $) *($ Insolation $) *(1-$ Albedo $) *($ Carnot efficiency $)$. Land area $=73260 \mathrm{~m}^{2}$; Insolation=hours of sunshine $* 3.6 \mathrm{E}+6\left(\mathrm{~J} / \mathrm{m}^{2} / \mathrm{yr}\right)$, hours of sunshine $=1.83 \mathrm{E}+3 \mathrm{~h} / \mathrm{yr}$; Albedo $=30 \%$ (Lou and Ulgiati, 2013); Carnot efficiency $=0.93$ (Brown and Ulgiati, 2016).

2. Wind energy $(\mathrm{J})=($ Land area $) *($ Air density $) *($ Drag coefficient $) *($ Geostrophic wind velocity $)$ ^3. Land area $=73260 \mathrm{~m}^{2}$; Air density $=1.293 \mathrm{~kg} / \mathrm{m}^{\wedge} 3$; Drag coefficient $=1.64 \mathrm{E}-03$ (Garratt, 1992); Geostrophic wind velocity=Annual average wind speed $/ 0.6=1.4 / 0.6 \mathrm{~m} / \mathrm{s}$.

3. Geothermal Heat Energy $(\mathrm{J})=($ Land area $) *($ Heat flow per area $) *($ Carnot efficiency $)$. Land area $=73260 \mathrm{~m}^{2}$; Heat flow per area $=45 \mathrm{mw} / \mathrm{m}^{2}==1.42 \mathrm{e}+6 \mathrm{~J} / \mathrm{m}^{2} / \mathrm{yr}$; Carnot efficiency $=9.5 \%($ Brown and Ulgiati, 2016).

4. Rainwater, chemical potential energy $(\mathrm{J})=($ Land area $) *($ Rainfall $) *($ Transpiration rate)*(Water density)*(Gibbs energy of rain). Land area $=73260 \mathrm{~m}^{2}$; Rainfall $=0.831 \mathrm{~m} / \mathrm{yr}$; 
Transpiration rate $=75 \%$ (Brown and Ulgiati, 2016); Water density $=1.00 \mathrm{E}+06 \mathrm{~g} / \mathrm{m}^{\wedge} 3$; Gibbs energy of rain=4.72J/g (Brown and Ulgiati, 2018).

5. Air quality $=10 *($ Natural gas volume $) *($ Air density $)$. Natural gas volume $=6.12 \mathrm{E}+06 \mathrm{~m}^{\wedge} 3$; Air density $=1.293 \mathrm{~kg} / \mathrm{m}^{\wedge} 3$.

7. Hydroelectricity energy $=($ Quantity $) *($ Energy content per quantity $)$. Quantity $=5.88 \mathrm{E}+06$

$\mathrm{kWh}$, Energy content per quantity $=3.6 \mathrm{E}+06 \mathrm{~J} / \mathrm{kWh}$.

9. Refer to UEV of carbonate.

12. Natural gas energy $=($ Volume $) *\left(\right.$ Energy content per volume. Volume $=6.12 \mathrm{E}+06 \mathrm{~m}^{\wedge} 3$, Energy content per volume $=3.55 \mathrm{E}+07 \mathrm{~J} / \mathrm{m}^{\wedge} 3$.

13. Salaries of staffs $(\$)=($ Salaries of staffs, $C N Y) *$ (The average exchange rate between us dollar and RMB). Salaries of staffs $=2.78 \mathrm{E}+06 \mathrm{CNY}$; the average exchange rate between us dollar and RMB in $2017=6.7518$.

Table A.2

Ecological services needed to dilute the air/water pollutants in this study (seJ/yr).

\begin{tabular}{|c|c|c|c|c|c|}
\hline Pollutants' name & $\begin{array}{c}\text { Annual } \\
\text { emissions(kg) }\end{array}$ & $\begin{array}{c}\text { Acceptable } \\
\text { concentration } \\
(\mathrm{mg} / \mathrm{m} 3, \mathrm{mg} / \mathrm{L})\end{array}$ & Reference & $\begin{array}{c}\text { Rair/water(s } \\
\text { eJ/yr) }\end{array}$ & $\mathrm{R}_{2}(\mathrm{seJ} / \mathrm{yr})$ \\
\hline Fumes(PM10) & $2.70 \mathrm{E}+03$ & 0.07 & (GB3095-2012)2level. & $3.86 \mathrm{E}+13$ & \\
\hline $\mathrm{SO}_{2}$ & $3.16 \mathrm{E}+04$ & 0.06 & (GB3095-2012)2level. & $5.27 \mathrm{E}+14$ & \\
\hline Lead dust & $7.78 \mathrm{E}+01$ & 0.0005 & (GB3095-2012)2level. & $1.56 \mathrm{E}+14$ & \\
\hline $\begin{array}{l}\text { Sulfuric acid } \\
\operatorname{mist}\left(\mathrm{H}_{2} \mathrm{SO}_{4}\right)\end{array}$ & $4.40 \mathrm{E}+03$ & 0.3 & (TJ36-79) & $1.47 \mathrm{E}+13$ & \\
\hline NMHC & $7.05 \mathrm{E}+02$ & 2 & (GB16297-1996)2level & $3.53 \mathrm{E}+11$ & \\
\hline COD & $3.67 \mathrm{E}+02$ & 20 & (GB3838-2002) III & $6.35 \mathrm{E}+17$ & \\
\hline $\mathrm{NH}_{3}-\mathrm{N}$ & $5.56 \mathrm{E}+01$ & 1 & (GB3838-2002) III & $1.92 \mathrm{E}+18$ & \\
\hline
\end{tabular}

Total ecological services

$1.92 \mathrm{E}+18$

1. (GB3095-2012) came from Ref. (Ministry of Environmental Protection of the People's Republic of China (2012)).

2. (TJ36-79) came from Ref. (Ministry of Health of the People's Republic of China (1979)).

3. (GB16297-1996) came from Ref. (Environmental protection bureau of the People's Republic of China (1996)).

4. (GB3838-2002) came from Ref. (Environmental protection administration of the People's Republic of China (2002)).

5. $\mathrm{v}=1.4 \mathrm{~m} / \mathrm{s}$.

Table A.3 
Emergy losses caused by the air/water pollutants in this study ${ }^{\mathrm{a}}$.

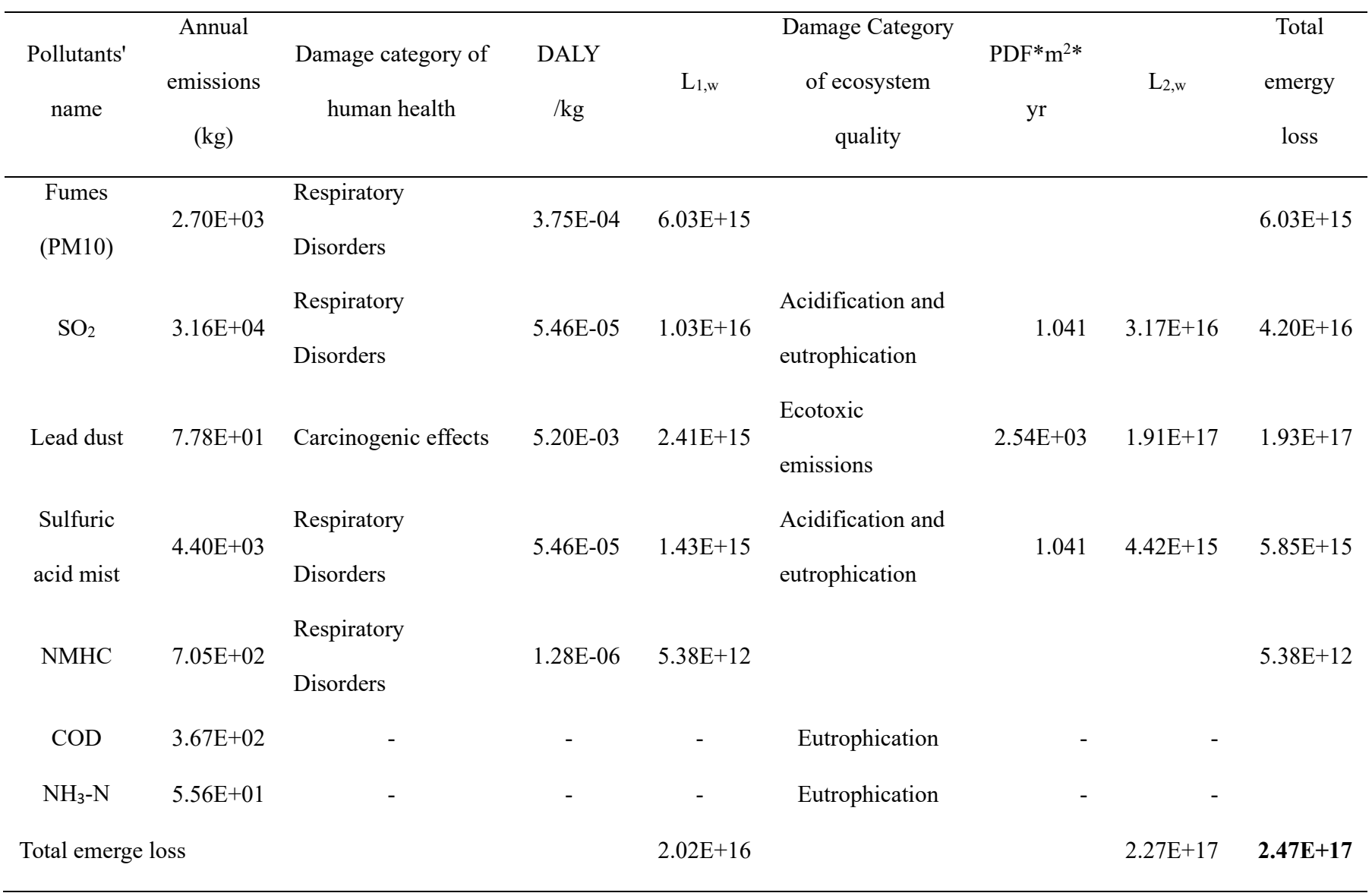

${ }^{a}$ Damage category and damage factors (DALY/kg and $\mathrm{PDF}^{*} \mathrm{~m}^{2 *} \mathrm{yr}$ ) of pollutants came from

Ref. (Goedkoop and Spriensma, 2000).

1. $\tau_{\mathrm{H}}=5.96 \mathrm{E}+15 \mathrm{sej} /$ person; $\mathrm{E}_{\mathrm{Bio}}=9.65 \mathrm{E}+11 \mathrm{sej} / \mathrm{m}^{\wedge} 2(\mathrm{Cao}, 2012)$.

Table B.1

Emergy analysis table of the cutting separation process.

\begin{tabular}{|c|c|c|c|c|c|c|}
\hline Items & $\begin{array}{c}\text { Unit } \\
\mathrm{s}\end{array}$ & Raw data & $\begin{array}{c}\mathrm{UEV} \text { (sej/uni } \\
\text { t) }\end{array}$ & Reference & $\begin{array}{c}\text { Solar } \\
\text { emergy(se } \\
\mathrm{j} / \mathrm{yr})\end{array}$ & $\begin{array}{l}\text { Percent of } \\
\text { item(\%) }\end{array}$ \\
\hline \multicolumn{5}{|c|}{ Total inputs(sum of 1-15) } & $1.00 \mathrm{E}+21$ & $100 \%$ \\
\hline \multicolumn{5}{|c|}{ Renewable Resources(R)(Sum of 1-7) } & $1.59 E+19$ & $1.58 \%$ \\
\hline 1.Sun & $\mathrm{J} / \mathrm{yr}$ & $1.02 \mathrm{E}+14$ & 1 & By definition & $1.02 \mathrm{E}+14$ & $0.00 \%$ \\
\hline 2.Wind & $\mathrm{J} / \mathrm{yr}$ & $1.02 \mathrm{E}+10$ & $7.90 \mathrm{E}+02$ & NEAD, 2014 & $8.06 \mathrm{E}+12$ & $0.00 \%$ \\
\hline 3.Geothermal Heat & $\mathrm{J} / \mathrm{yr}$ & $6.43 \mathrm{E}+09$ & $4.90 \mathrm{E}+03$ & NEAD, 2014 & $3.15 \mathrm{E}+13$ & $0.00 \%$ \\
\hline 4.Rainwater & $\mathrm{J} / \mathrm{yr}$ & $1.33 \mathrm{E}+11$ & $7.01 \mathrm{E}+03$ & NEAD, 2014 & $9.32 \mathrm{E}+14$ & $0.00 \%$ \\
\hline 5.Air & $\mathrm{t} / \mathrm{yr}$ & $1.94 \mathrm{E}+04$ & $3.91 \mathrm{E}+13$ & Wang et al., 2005 & $7.59 \mathrm{E}+17$ & $0.08 \%$ \\
\hline 6. Water & $\mathrm{t} / \mathrm{yr}$ & $7.50 \mathrm{E}+03$ & $5.03 \mathrm{E}+11$ & Wang et al., 2005 & $3.78 \mathrm{E}+15$ & $0.00 \%$ \\
\hline 7.Hydroelectricity & $\mathrm{J} / \mathrm{yr}$ & $4.32 \mathrm{E}+13$ & $3.50 \mathrm{E}+05$ & NEAD, 2014 & $1.51 \mathrm{E}+19$ & $1.51 \%$ \\
\hline \multicolumn{5}{|c|}{ Nonrenewable Resources(N) (Sum of 8-10) } & $9.81 E+20$ & $97.85 \%$ \\
\hline 8.LABs & $\$ / y r$ & $2.67 \mathrm{E}+08$ & $3.55 \mathrm{E}+12$ & NEAD, 2014 & $9.46 \mathrm{E}+20$ & $94.43 \%$ \\
\hline 9.Liquid ammonia & $\mathrm{t} / \mathrm{yr}$ & $5.47 \mathrm{E}+03$ & $4.90 \mathrm{E}+15$ & Liu and Yang, 2018 & $2.68 \mathrm{E}+19$ & $2.68 \%$ \\
\hline 10.Natural gas & $\mathrm{J} / \mathrm{yr}$ & $5.33 \mathrm{E}+13$ & $1.40 \mathrm{E}+05$ & NEAD, 2014 & $7.46 \mathrm{E}+18$ & $0.74 \%$ \\
\hline
\end{tabular}


Input from economy(F) (Sum of 11-15)

11.Staffs salaries
12.Equipment
13.Equipment
14.Environmental
15.Environmental
Outputs(sum of 16-20)

16.Lead antimony alloy

17.Lead calcium alloy

18.Lead oxide

19.Plastic

20.Ammonium sulfate

Waste(sum of 21-23)

21.Air pollutants

$\begin{array}{lll}\text { Fumes } & \mathrm{kg} / \mathrm{y} & 1.12 \mathrm{E}+03 \\ \mathrm{SO}_{2} & \mathrm{~kg} / \mathrm{y} & 8.10 \mathrm{E}+02 \\ \text { Lead dust } & \mathrm{kg} / \mathrm{y} & 1.90 \mathrm{E}+01 \\ \text { Sulfuric acid } & \mathrm{kg} / \mathrm{y} & 3.72 \mathrm{E}+02 \\ \mathrm{NO}_{2} & \mathrm{~kg} / \mathrm{y} & 3.12 \mathrm{E}+03 \\ \mathrm{Ammonia} \mathrm{fog}\left(\mathrm{NH}_{3}\right) & \mathrm{kg} / \mathrm{y} & 1.44 \mathrm{E}+03 \\ \mathrm{NMHC} & \mathrm{kg} / \mathrm{y} & 7.05 \mathrm{E}+02 \\ \text { 22.Water pollutants } & & \\ \mathrm{COD} & \mathrm{kg} / \mathrm{y} & 2.40 \mathrm{E}+02 \\ \mathrm{NH}_{3}-\mathrm{N} & \mathrm{kg} / \mathrm{y} & 3.00 \mathrm{E}+01 \\ \text { 23.Solid pollutants } & & \\ \text { Paper partition } & \mathrm{kg} / \mathrm{y} & 1.60 \mathrm{E}+07 \\ \text { Lead slag } & \mathrm{kg} / \mathrm{y} & 8.77 \mathrm{E}+05 \\ \text { Other waste } & \mathrm{kg} / \mathrm{y} & 6.90 \mathrm{E}+03\end{array}$

$\begin{array}{llrr} & & \mathbf{5 . 7 0 E}+\mathbf{1 8} & \mathbf{0 . 5 7 \%} \\ 3.55 \mathrm{E}+12 & \text { NEAD, 2014 } & 1.80 \mathrm{E}+18 & 0.18 \% \\ 3.55 \mathrm{E}+12 & \text { NEAD, 2014 } & 1.26 \mathrm{E}+18 & 0.13 \% \\ 3.55 \mathrm{E}+12 & \text { NEAD, 2014 } & 6.31 \mathrm{E}+17 & 0.06 \% \\ 3.55 \mathrm{E}+12 & \text { NEAD, 2014 } & 5.34 \mathrm{E}+17 & 0.05 \% \\ 3.55 \mathrm{E}+12 & \text { NEAD, 2014 } & 1.47 \mathrm{E}+18 & 0.15 \% \\ 3.55 \mathrm{E}+12 & \text { NEAD, 2014 } & \mathbf{1 . 4 8 E}+\mathbf{2 1} & \mathbf{1 0 0 \%} \\ 3.55 \mathrm{E}+12 & \text { NEAD, 2014 } & 1.58 \mathrm{E}+20 & 10.63 \% \\ 3.55 \mathrm{E}+12 & \text { NEAD, 2014 } & 4.23 \mathrm{E}+20 & 28.47 \% \\ 2.40 \mathrm{E}+15 & \text { Brown and Ulgiati, 2004 } & 8.68 \mathrm{E}+20 & 58.46 \% \\ 3.55 \mathrm{E}+12 & \text { NEAD, 2014 } & 7.88 \mathrm{E}+19 & 1.94 \% \\ & & 7.41 \mathrm{E}+18 & 0.50 \%\end{array}$

1. Solar energy $(\mathrm{J})=($ Land area $) *($ Insolation $) *(1-A l b e d o) *($ Carnot efficiency). Land area $=33000 \mathrm{~m}^{2}$; Insolation=hours of sunshine $* 3.6 \mathrm{E}+6\left(\mathrm{~J} / \mathrm{m}^{2} / \mathrm{yr}\right)$, hours of sunshine $=1.32 \mathrm{E}+3 \mathrm{~h} / \mathrm{yr}$; Albedo=30\% (Lou and Ulgiati, 2013); Carnot efficiency=0.93(Brown and Ulgiati, 2016).

2. Wind energy $(\mathrm{J})=($ Land area $) *($ Air density $) *($ Drag coefficient $) *($ Geostrophic wind velocity) ${ }^{\wedge} 3$. Land area $=33000 \mathrm{~m}^{2}$; Air density $=1.293 \mathrm{~kg} / \mathrm{m}^{\wedge} 3$; Drag coefficient $=1.64 \mathrm{E}-03$ (Garratt, 1992); Geostrophic wind velocity=Annual average wind speed $/ 0.6=1.0 / 0.6 \mathrm{~m} / \mathrm{s}$.

3. Geothermal Heat Energy $(\mathrm{J})=($ Land area $) *($ Heat flow per area $) *($ Carnot efficiency $)$. Land area $=33000 \mathrm{~m}^{2}$; Heat flow per area $=65 \mathrm{mw} / \mathrm{m} 2==2.05 \mathrm{e}+6 \mathrm{~J} / \mathrm{m} 2 / \mathrm{yr}$; Carnot efficiency $=9.5 \%($ Brown and Ulgiati, 2016).

4. Rain, chemical potential energy $(\mathrm{J})=($ Land area $) *($ Rainfall $) *($ Transpiration rate $) *($ Water density)*(Gibbs energy of rain). Land area $=33000 \mathrm{~m}^{2}$; Rainfall $=1.14 \mathrm{~m} / \mathrm{yr}$; Transpiration rate $=75 \%$ (Brown and Ulgiati, 2016); Water density $=1.00 \mathrm{E}+06 \mathrm{~g} / \mathrm{m}^{\wedge} 3$; Gibbs energy of rain=4.72J/g (Brown and Ulgiati, 2018).

5. Air quality $=10 *($ Natural gas volume $) *($ Air density $)$. Natural gas volume $=1.50 \mathrm{E}+06 \mathrm{~m}^{\wedge} 3$; Air density $=1.293 \mathrm{~kg} / \mathrm{m}^{\wedge} 3$. 
7. Hydroelectricity energy $=($ Quantity $) *($ Energy content per quantity $)$. Quantity $=1.20 \mathrm{E}+$ $07 \mathrm{kWh}$, Energy content per quantity $=3.6 \mathrm{E}+06 \mathrm{~J} / \mathrm{kWh}$.

10. Natural gas energy $=($ Volume $) *\left(\right.$ Energy content per volume. Volume $=1.50 \mathrm{E}+06 \mathrm{~m}^{\wedge} 3$, Energy content per volume $=3.55 \mathrm{E}+07 \mathrm{~J} / \mathrm{m}^{\wedge} 3$

11. Salaries of staffs $(\$)=($ Salaries of staffs, $C N Y) *($ The average exchange rate between us dollar and RMB). Salaries of staffs $=3.42 \mathrm{E}+06 \mathrm{CNY}$; the average exchange rate between us dollar and RMB in $2017=6.7518$.

\section{Table B.2}

Ecological services needed to dilute the air/water pollutants in this study (seJ/yr).

\begin{tabular}{|c|c|c|c|c|c|}
\hline Pollutants' name & $\begin{array}{c}\text { Annual } \\
\text { emissions(kg) }\end{array}$ & $\begin{array}{c}\text { Acceptable } \\
\text { concentration } \\
(\mathrm{mg} / \mathrm{m} 3, \mathrm{mg} / \mathrm{L})\end{array}$ & Reference & $\begin{array}{c}\text { Rair/water } \\
\text { (seJ/yr) }\end{array}$ & $\mathrm{R}_{2}(\mathrm{seJ} / \mathrm{yr})$ \\
\hline \multicolumn{6}{|l|}{ Air pollutants } \\
\hline Fumes(PM10) & $1.12 \mathrm{E}+03$ & 0.07 & (GB3095-2012)2level. & $8.14 \mathrm{E}+12$ & \\
\hline $\mathrm{SO}_{2}$ & $8.10 \mathrm{E}+02$ & 0.06 & (GB3095-2012)2level. & $6.89 \mathrm{E}+12$ & \\
\hline Lead dust & $1.90 \mathrm{E}+01$ & 0.0005 & (GB3095-2012)2level. & $1.94 \mathrm{E}+13$ & \\
\hline $\begin{array}{l}\text { Sulfuric acid } \\
\operatorname{mist}\left(\mathrm{H}_{2} \mathrm{SO}_{4}\right)\end{array}$ & $3.72 \mathrm{E}+02$ & 0.3 & (TJ36-79) & $6.33 \mathrm{E}+11$ & \\
\hline $\mathrm{NO}_{2}$ & $3.12 \mathrm{E}+03$ & 0.04 & (GB3095-2012)2level. & $3.98 \mathrm{E}+13$ & \\
\hline $\mathrm{NH}_{3}$ & $1.44 \mathrm{E}+03$ & 0.2 & (TJ36-79) & $3.68 \mathrm{E}+12$ & \\
\hline NMHC & $1.41 \mathrm{E}+03$ & 2 & (GB16297-1996)2level & $3.60 \mathrm{E}+11$ & \\
\hline \multicolumn{6}{|l|}{$\begin{array}{l}\text { Water } \\
\text { pollutants }\end{array}$} \\
\hline COD & $2.40 \mathrm{E}+02$ & 20 & (GB3838-2002) III & $4.16 \mathrm{E}+17$ & \\
\hline $\mathrm{NH}_{3}-\mathrm{N}$ & $3.00 \mathrm{E}+01$ & 1 & (GB3838-2002) III & $1.04 \mathrm{E}+18$ & \\
\hline Total ecological s & vices & & & & $1.04 \mathrm{E}+18$ \\
\hline
\end{tabular}

$1 . \mathrm{v}=1.0 \mathrm{~m} / \mathrm{s}$.

Table B.3

Emergy losses caused by the air/water pollutants in this study ${ }^{\mathrm{a}}$.

\begin{tabular}{|c|c|c|c|c|c|c|c|c|}
\hline $\begin{array}{l}\text { Pollutants' } \\
\text { name }\end{array}$ & $\begin{array}{l}\text { Annual } \\
\text { emissions } \\
(\mathrm{kg})\end{array}$ & $\begin{array}{l}\text { Damage } \\
\text { category of } \\
\text { human } \\
\text { health }\end{array}$ & $\mathrm{DALY} / \mathrm{kg}$ & $\mathrm{L}_{1, \mathrm{w}}$ & $\begin{array}{l}\text { Damage Category } \\
\text { of ecosystem } \\
\text { quality }\end{array}$ & $\begin{array}{l}\mathrm{PDF}^{*} \mathrm{~m}^{2 *} \\
\mathrm{yr}\end{array}$ & $\mathrm{L}_{2, \mathrm{w}}$ & $\begin{array}{l}\text { Total } \\
\text { emergy loss }\end{array}$ \\
\hline $\begin{array}{l}\text { Fumes } \\
\text { (PM10) }\end{array}$ & $1.12 \mathrm{E}+03$ & $\begin{array}{l}\text { Respiratory } \\
\text { Disorders }\end{array}$ & $3.75 \mathrm{E}-04$ & $3.62 \mathrm{E}+15$ & - & - & - & $3.62 \mathrm{E}+15$ \\
\hline $\mathrm{SO}_{2}$ & $8.10 \mathrm{E}+02$ & $\begin{array}{l}\text { Respiratory } \\
\text { Disorders }\end{array}$ & $5.46 \mathrm{E}-05$ & $3.82 \mathrm{E}+14$ & $\begin{array}{l}\text { Acidification and } \\
\text { eutrophication }\end{array}$ & 1.041 & $4.36 \mathrm{E}+14$ & $8.18 \mathrm{E}+14$ \\
\hline Lead dust & $1.90 \mathrm{E}+01$ & $\begin{array}{l}\text { Carcinogeni } \\
\text { c effects }\end{array}$ & $5.20 \mathrm{E}-03$ & $8.54 \mathrm{E}+14$ & $\begin{array}{l}\text { Ecotoxic } \\
\text { emissions }\end{array}$ & $2.54 \mathrm{E}+03$ & $2.50 \mathrm{E}+16$ & $2.58 \mathrm{E}+16$ \\
\hline $\begin{array}{l}\text { Sulfuric } \\
\text { acid mist }\end{array}$ & $3.72 \mathrm{E}+02$ & $\begin{array}{l}\text { Respiratory } \\
\text { Disorders }\end{array}$ & $5.46 \mathrm{E}-05$ & $1.75 \mathrm{E}+14$ & $\begin{array}{l}\text { Acidification and } \\
\text { eutrophication- } \\
\text { SOx }\end{array}$ & 1.041 & $2.00 \mathrm{E}+14$ & $3.76 \mathrm{E}+14$ \\
\hline NMHC & $1.41 \mathrm{E}+03$ & $\begin{array}{l}\text { Respiratory } \\
\text { Disorders }\end{array}$ & $1.28 \mathrm{E}-06$ & $1.56 \mathrm{E}+13$ & - & - & - & $1.56 \mathrm{E}+13$ \\
\hline $\mathrm{NO}_{2}$ & $3.12 \mathrm{E}+03$ & $\begin{array}{l}\text { Respiratory } \\
\text { Disorders }\end{array}$ & 8.87E-05 & $2.39 \mathrm{E}+15$ & $\begin{array}{l}\text { Acidification and } \\
\text { eutrophication }\end{array}$ & 5.713 & $9.22 \mathrm{E}+15$ & $1.16 \mathrm{E}+16$ \\
\hline $\mathrm{NH}_{3}$ & $1.44 \mathrm{E}+03$ & Respiratory & $8.50 \mathrm{E}-05$ & $1.06 \mathrm{E}+15$ & Acidification and & 15.57 & $1.16 \mathrm{E}+16$ & $1.26 \mathrm{E}+16$ \\
\hline
\end{tabular}




\begin{tabular}{|c|c|c|c|c|c|c|c|c|}
\hline \multirow[b]{2}{*}{ COD } & \multicolumn{3}{|c|}{ Disorders } & \multicolumn{3}{|c|}{ eutrophication } & \multirow[b]{2}{*}{ - } & \multirow[b]{2}{*}{-} \\
\hline & $3.67 \mathrm{E}+02$ & - & - & - & Eutrophication & - & & \\
\hline $\mathrm{NH}_{3}-\mathrm{N}$ & $5.56 \mathrm{E}+01$ & - & 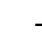 & - & Eutrophication & - & - & - \\
\hline \multicolumn{2}{|c|}{ Total emerge loss } & & & $8.49 \mathrm{E}+$ & & & $4.64 \mathrm{E}+16$ & $5.49 \mathrm{E}+16$ \\
\hline
\end{tabular}

\section{References}

Almeida, C.M.V.B., et al., 2018. Accounting for the benefits of technology change: Replacing a zinc-coating process by a water-based organo-metallic coating process. Journal of Cleaner Production. 174,170-176. https://doi.org/10.1016/j.jclepro.2017.10.192.

Battaïa, Olga, et al., 2018. Design for manufacturing and assembly/disassembly: joint design of products and production systems. International Journal of Production Research. 56:24, 7181-7189. https://doi.org/10.1080/00207543.2018.1549795.

Brown, M T, Ulgiati, S., 1997. Emergy-based indices and ratios to evaluate sustainability: monitoring economies and technology toward environmentally sound innovation. Ecological Engineering.9 (1-2), 51-69. https://doi.org/10.1016/S0925-8574(97)00033-5.

Brown, M.T., Ulgiati, S., 2004. Energy quality, emergy, and transformity: H.T.Odum's contributions to quantifying and understanding systems. Ecological Modelling. 178(1), 201-213. https://doi.org/10.1016/j.ecolmodel.2004.03.002.

Brown, M.T., Ulgiati, S., 2010. Updated evaluation of exergy and emergy driving the geobiosphere: a review and refinement of the emergy baseline. Ecological Modelling. 221(20), 2501-2508. https://doi.org/10.1016/j.ecolmodel.2010.06.027.

Brown, M.T., Ulgiati, S., 2016. Assessing the global environmental sources driving the geobiosphere: a revised emergy baseline. Ecological Modelling. 339, 126-132. https://doi.org/10.1016/j.ecolmodel.2016.03.017.

Brown, M.T., Ulgiati, S., 2018. Environmental Accounting: Coupling Human and Natural Systems. New York: Springer.

Bühler, Fabian, et al., 2018. Energy, exergy and advanced exergy analysis of a milk processing factory. Energy. 162,576-592. https://doi.org/10.1016/j.energy.2018.08.029.

Campbell, Daniel E., Garmestani, Ahjond S., 2012.An energy systems view of sustainability: Emergy evaluation of the San Luis Basin, Colorado. Journal of Environmental Management. 95 (1), 72-97. https://doi.org/10.1016/j.jenvman.2011.07.028.

Cai, Wei, et al., 2019. Promoting sustainability of manufacturing industry through the lean energysaving and emission reduction strategy. Science of the Total Environment. 665, 23-32. https://doi.org/10.1016/j.scitotenv.2019.02.069.

Cao, Jingjing. 2012. Assessment and prediction on ecological security of Hubei Province based on the emergy and ecological footprint model. Master's degree, Hubei University (in Chinese). 
Chang, Yu, et al., 2009. Lead-acid battery use in the development of renewable energy systems in $\begin{array}{lllll}\text { China. Journal of } & \text { Power }\end{array}$ https://doi.org/10.1016/j.jpowsour.2009.02.030.

Fang, Delin, et al., 2017. Emergy evaluation for a low-carbon industrial park. Journal of Cleaner Production. 163, S392-S400. https://doi.org/10.1016/j.jclepro.2015.10.122.

Garratt, J R, 1992. The Atmospheric Boundary Layer: Cambridge Atmospheric and Space Science Series. Cambridge, UK: Cambridge University Press.

Goedkoop, Mark, Spriensma, Renilde, 2000. The eco-indicator 99: A damage oriented method for life cycle impact assessment: Methodology report. Amersfoort: Pre Consultants. B.V., 113-118.

Henry, C. Michael. 2005. The end of poverty: how we can make it happen in our lifetime. Review of Book the end of poverty, by Jeffrey Sachs Lond. The Review of Black Political Economy. 33(2), 61-68. https://doi.org/10.1007/s12114-005-1015-9.

Jiang, Zhigang, et al., $2019 . \quad$ Datadriven ecological performance evaluation for remanufacturing process. Energy Conversion and $\mathrm{M}$ anagement. https://doi.org/10.1016/j.enconman.2019.111844.

Liu, Conghu, et al., 2018. Emergy-based evaluation and improvement for sustainable manufacturing systems considering resource efficiency and environment performance. Energy Conversion and Management. 177, 176-189. https://doi.org/10.1016/j.enconman.2018.09.039.

Liu, Gengyuan, et al., 2015. Scenarios for sewage sludge reduction and reuse in clinker production towards regional eco-industrial development: a comparative emergy-based assessment. Journal of Cleaner Production .103:371-383. https://doi.org/10.1016/j.jclepro.2014.09.003.

Liu, Gengyuan, Yang, Zhifeng, 2018. Emergy Theory and practice: ecological environmental accounting and urban green management. Beijing: science Press (in Chinese).

Liu, Wei, et al., 2015. Life cycle assessment of lead-acid batteries used in electric bicycles in China. Journal of Cleaner Production. 108, 1149-1156. https://doi.org/10.1016/j.jclepro.2015.07.026.

Lou, Bo, Ulgiati, S., 2013. Identifying the environmental support and constraints to the Chinese economic growth-an application of the emergy accounting method. Energy Policy. 55,217-233. https://doi.org/10.1016/j.enpol.2012.12.009.

Lu, Bin, Liu, Jingru, Yang, Jianxin, 2016. Substance flow analysis of lithium for sustainable management in mainland China: 2007-2014. Resources, Conservation and Recycling.119, 109116. https://doi.org/10.1016/j.resconrec.2016.05.015.

NEAD (National Environmental Accounting Database V2.0), 2014. Country: China, year: 2014. http://nead.um01.cn/country/data (Accessed 5 March 2019).

Nimmanterdwong, Prathana, Chalermsinsuwan, Benjapon, Piumsomboon, Pornpote, 2015. Emergy evaluation of biofuels production in Thailand from different feedstocks. Ecological Engineering.74:423-437. https://doi.org/10.1016/j.ecoleng.2014.11.017.

Odum, H T., 1996. Environmental accounting: Emergy and environmental decision making. New York: John Wiley \& Sons. 
Pan, Hengyu, et al., 2016a. Emergy evaluation of an industrial park in Sichuan Province, China: a modified emergy approach and its application. Journal of Cleaner Production. 135, 105-118. https://doi.org/10.1016/j.jclepro.2016.06.102.

Pan, Hengyu, et al., 2016b. Sustainability evaluation of a steel production system in China based on emergy. Journal of Cleaner Production. 112, 1498-1509. https://doi.org/10.1016/j.jclepro.2015.05.019.

Pan, Hengyu, et al., 2018. An emergy based sustainability evaluation on a combined landfill and LFG power generation system. Energy. 143,310-322. https://doi.org/10.1016/j.energy.2017.10.144.

Pan, Hengyu, et al., 2019.Sustainability evaluation of secondary lead production from spent lead acid batteries recycling. Resources, Conservation and Recycling. 140, 13-22. https://doi.org/10.1016/j.resconrec.2018.09.012.

Pan, Yuxue, Li, Haitao, 2016. Sustainability evaluation of end-of-life vehicle recycling based on emergy analysis: a case study of an end-of-life vehicle recycling enterprise in China. Journal of cleaner production.131, 219-227. https://doi.org/10.1016/j.jclepro.2016.05.045.

Reza, Bahareh, Sadiq, Rehan, Hewage, Kasun, 2014. Emergy-based life cycle assessment (EmLCA) for sustainability appraisal of infrastructure systems: a case study on paved roads. Clean Technologies and Environmental Policy. 16(2), 251-266. https://doi.org/10.1007/s10098-013-0615-5.

Rydberg, Torbjörn, Haden, Andrew C., 2006. Emergy evaluations of Denmark and Danish agriculture: Assessing the influence of changing resource availability on the organization of agriculture and society. Agriculture Ecosystems \& Environment .117(2-3), 145-158. https://doi.org/10.1016/j.agee.2006.03.025.

Sandouqa, Arwa, Al-Hamamre, Zayed, 2019. Energy analysis of biodiesel production from jojoba seed oil. Renewable Energy. 130,831-842. https://doi.org/10.1016/j.renene.2018.07.015.

Santagata, Remo, et al., 2019. Power generation from slaughterhouse waste materials. An emergy accounting assessment. Journal of Cleaner Production. 223, 536-552. https://doi.org/10.1016/j.jclepro.2019.03.148.

Shen, Jianming, et al., 2019.An improved emergy evaluation of the environmental sustainability of China's steel production from 2005 to 2015.Ecological Indicators. 103, 55-69. https://doi.org/10.1016/j.ecolind.2019.03.051.

Song, Qingbin, Wang, Zhishi, Li, Jinhui, Duan, Huabo, 2012.Sustainability evaluation of an e-waste treatment enterprise based on emergy analysis in China. Ecological Engineering.42, 223-231. https://doi.org/10.1016/j.ecoleng.2012.02.016.

Song, Qingbin, Wang, Zhishi, Li, Jinhui. 2013. Sustainability evaluation of e-waste treatment based on emergy analysis and the LCA method: A case study of a trial project in Macau. Ecological Indicators.30, 138-147. https://doi.org/10.1016/j.ecolind.2013.02.016.Sun, Zhi, et al., 2017. Spent lead-acid battery recycling in China - a review and sustainable analyses on mass flow of lead. Waste Management. 64, 190-201. 
https://doi.org/10.1016/j.wasman.2017.03.007.

Tang, Lian, Quan, Guan, Hu, Xiaohui, XieShiyou, 2017. Sustainable development of ecological economic system based on emergetic ecological footprint in Guizhou. Guizhou Agricultural Science.45 (04), 150-156 (in Chinese).

Tian, Xi, et al., 2018. Modeling domestic geographical transfers of toxic substances in WEEE: A case study of spent lead-acid batteries in China. Journal of Cleaner Production.198, 1559-1566. https://doi.org/10.1016/j.jclepro.2018.07.089.

Treptow, Richard, S., 2002. The Lead-Acid Battery: Its Voltage in Theory and in Practice. Journal of Chemical Education. 79(3), 334-338. https://doi.org/10.1021/ed079p334.

Ulgiati, Sergio, Brown, Mark T, 2002. Quantifying the environmental support for dilution and abatement of process emissions: The case of electricity production. Journal of Cleaner Production. 10 (4), 335-348. https://doi.org/10.1016/S0959-6526(01)00044-0.

Voelker, Doris, et al., 2015. Approach on environmental risk assessment of nanosilver released from textiles. Environmental Research.140, 661-672. https://doi.org/10.1016/j.envres.2015.05.011.

Wang, Lingmei, Zhang, Jintun, Ni, Weidou, 2005. Emergy evaluation of eco-industrial park with power plant. Ecological Modelling. 189(1-2), 233-240. https://doi.org/10.1016/j.ecolmodel.2005.02.005.

$\mathrm{Wu}$, Xihui, et al., 2015. Emergy and greenhouse gas assessment of a sustainable, integrated agricultural model (SIAM) for plant, animal and biogas production: analysis of the ecological recycle of wastes. Resources, Conservation and Recycling. 96, 40-50. https://doi.org/10.1016/j.resconrec.2015.01.010.

Yang, Hui, et al, 2003. Evaluating waste treatment, recycle and reuse in industrial system: an application of the eMergy approach. Ecological Modelling. 160(1-2), 13-21. https://doi.org/10.1016/S0304-3800(02)00288-0. 